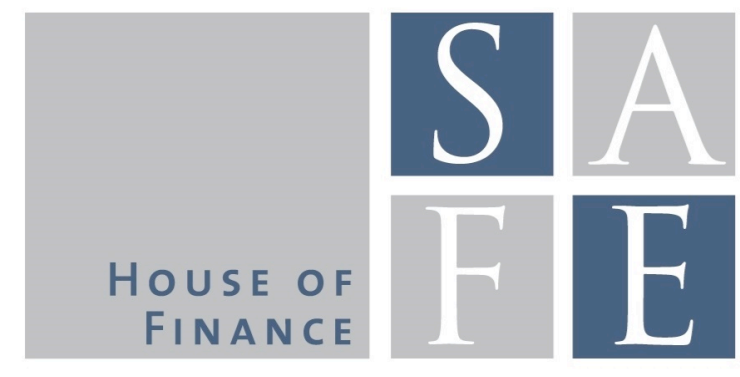

WORKING PAPER SERIES

Tobias H. Tröger

\title{
Germany's Reluctance to Regulate Related Party Transactions
}

SAFE Working Paper No. 202

SAFE I Sustainable Architecture for Finance in Europe A cooperation of the Center for Financial Studies and Goethe University Frankfurt 


\title{
GERMANY'S RELUCTANCE TO REGULATE RELATED PARTY
}

\section{TRANSACTIONS \\ AN INDUSTRIAL ORGANIZATION PERSPECTIVE}

A chapter for Luca Enriques and Tobias H. Tröger, eds., The Law and Finance of Related Party Transactions (Cambridge University Press, forthcoming)

\author{
(February 15, 2018) \\ Tobias H. Tröger

Theodor-W.-Adorno Platz 3
60629 Frankfurt am Main
Germany
Phone +49 6979834236
Fax +49 6979834536
troeger@jur.uni-frankfurt.de

Professor of Private Law, Trade and Business Law, Jurisprudence

Goethe-University, Frankfurt am Main, Department of Law

Abstract: Germany Inc. was an idiosyncratic form of industrial organization that put financial institutions at the center. This paper argues that the consumption of private benefits in related party transactions by these key agents can be understood as a compensation for their coordinating and monitoring function in Germany Inc. As a consequence, legal tools apt to curb tunneling remained weak in Germany from the perspective of outside shareholders. While banks were in a position to use their firm-level knowledge and influence to limit rent-seeking by other related parties, their own behavior was not subject to meaningful controls. With the dismantling of Germany Inc. banks seized their monitoring function and left an unprecedented void with regard to related party transactions. Hence, a "traditionalist" stance which opposes law reform for related party transactions in Germany negatively affects capital market development, growth opportunities and ultimately social welfare.

Keywords related party transactions, Germany Inc., industrial organization, tunneling, private benefits of control, capital maintenance, group law.

JEL classification: D23, D62, K22 


\title{
GERMANY'S RELUCTANCE TO REGULATE RELATED PARTY TRANSACTIONS
}

\author{
AN INDUSTRIAL ORGANIZATION PERSPECTIVE
}

Tobias H. Tröger*

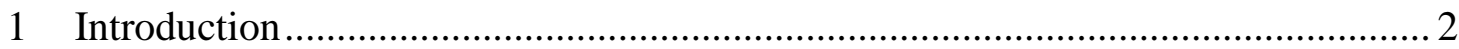

2 Main features of Germany Inc. .................................................................... 5

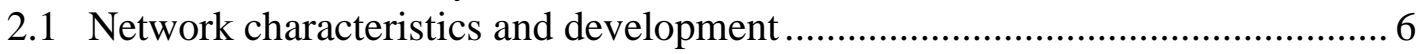

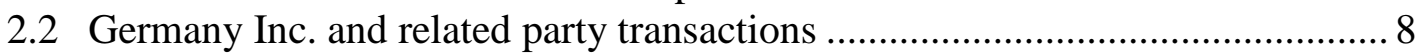

3 Minority protection in German corporate and securities laws in the context of

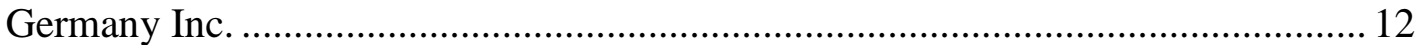

3.1 Capital maintenance and the doctrine of hidden distributions........................ 12

3.2 Prohibition to act to the detriment of the corporation in corporate group law 14

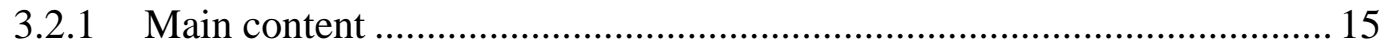

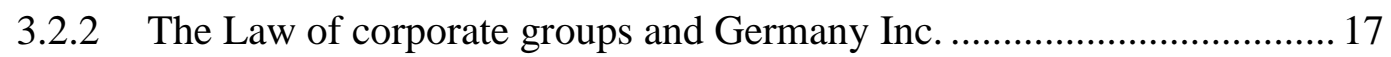

3.3 Corporate law reform of 1937 ................................................................ 19

3.4 Industrial organization as key determinant for a lenient approach to related party transactions in corporate law .......................................................... 20

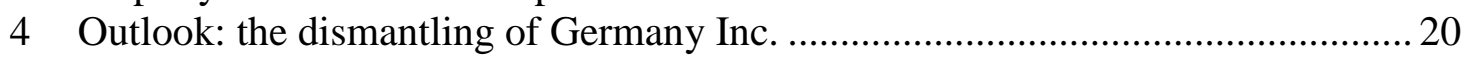

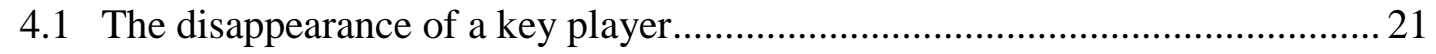

4.2 Why existing securities laws and accounting standards are not enough ......... 22

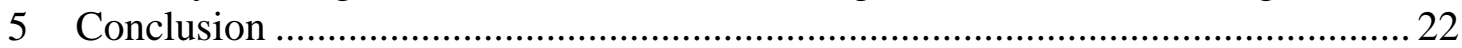

* Professor of Private Law, Trade and Business Law, Jurisprudence, Goethe University Frankfurt am Main, Germany. Program Director Corporate Finance and Corporate Governance Research Center Sustainable Architecture for Finance in Europe (SAFE). This chapter has benefited tremendously from comments and critique colleagues and friends made on earlier drafts. Those of Marc Amstutz, Paul Davies, Ronald Gilson, and Luca Enriques were particularly beneficial. The author gratefully acknowledges financial support of the LOEWE Research Center SAFE. 


\section{INTRODUCTION}

The regulation of related party transactions that can facilitate private rent-seeking by controllers features high on the agenda of policy makers around the world. ${ }^{1}$ The rationale that underpins this focus refers to the negative impact that an inadequate regime for related party transactions has on capital market development, ultimately curbing growth opportunities and decreasing social welfare. ${ }^{2}$

Although the specifics of an efficient regulatory framework that prevents undesirable tunneling ${ }^{3}$ but permits value-enhancing transactions with controlling insiders are far from obvious, ${ }^{4}$ Germany's consistent and recurring rejection of reform efforts that seek to tighten the direct grip on tainted transactions is remarkable. The most recent evidence of this attitude is the

${ }^{1}$ See for instance ORG. ECON. DEV. \& COOPERATION, RElated PARTY TRANSACTIONS AND MiNORITY SHAREHOLDER RIGHTS (2012); THE WORLD BANK \& INT'L FIN. CORP., DOING BUSINESS 2014 96-7 (2013);

${ }^{2}$ See Merrit B. Fox \& Michael A. Heller, What is good corporate governance?, in CORPORATE GOVERNANCE LESSONS FROM TRANSITION ECONOMY REFORMS 1, 19 (Merrit B. Fox \& Michael A. Heller eds., 2006) (arguing that the IPO-market may face a lemon-problem if controllers cannot credibly bond to non-value extracting strategies ex ante); Lucian A. Bebchuk, Efficient and inefficient sales of corporate control, 109 Q. J. ECON. 957, 976-9 (1994) (showing that even value enhancing control-transactions may be chilled if only incumbents are able to consume private benefits of control that cancel out returns from efficiency gains that accrue to potential acquirers on a pro rata basis); Lucian A. Bebchuk, A Rent Protection Theory of Corporate Ownership and Control (Nat'l Bureau of Econ. Research, Working Paper No. w7203, 1999), http://www.nber.org/papers/w7203 (devising a model to prove that blockholders will not sell-off their control-stakes if significant tunneling opportunities exist).

${ }^{3}$ For the formative article see Simon Johnston et al., Tunneling, 90 AM. ECON. REV. 22 (2000). For a more granular taxonomy of pertinent transactions see Vladimir Atanasov, Bernard S. Black \& Conrad S. Ciccotello, Law and Tunneling, 37 J. CORP. L. 1, 5-9 (2011) (distinguishing the misappropriation of cash flow, asset and equity entitlements).

${ }^{4}$ Related party transactions need not involve private rent-seeking, see for instance Luca Enriques, Related Party Transactions: Policy Options and Real-World Challenges (with a Critique of the European Commission Proposal), 15 EUR. BUS. ORG. L. REV. 1, 7 (2015) (pointing to value enhancing transactions for which outside counterparties are not readily available). To complicate things further, even where value extraction occurs, the efficient solution might not even consist of a strict prohibition, see infra note 15 . 
successful resistance, fueled also by policy-oriented contributions from academics, ${ }^{5}$ to the respective rule in the recast E.U. Shareholder Rights Directive. ${ }^{6}$ As a result the restrictions originally foreseen by the European Commission were considerably watered down in the legislative process. $^{7}$

This chapter looks through the superficial rhetoric that identifies a neglected divergence between the internal governance structure of companies in the continental European civil law tradition on the one hand and the common law family on the other as the substantive reason for legitimate opposition. ${ }^{8}$ Instead, it advances an explanation that hinges on long-standing industrial organization particularities: the significant shareholdings, primarily of financial institutions, and the interlocked management functions in deeply hierarchized corporate groups typically referred to as Germany Inc. ("Deutschland AG"). These idiosyncrasies entail a normatively different, far more positive assessment of, at least a subset of related party transactions

${ }^{5}$ See for instance Uwe H. Schneider, Europarechtlicher Schutz vor nachteiligen Transaktionen mit nahe stehenden Unternehmen und Personen, EUROPÄISCHE ZEITSCHRIFT FÜR WIRTSCHAFTSRECHT [EuZW] 641 (2014); Peter Hommelhoff, Ein Neustart im europäischen Konzernrecht, 5 KÖLNER SCHRIFT ZUM WIRTSCHAFTSRECHT [KSZW] 63, 66-7 (2014); for less fierce opposition, that still rejected the proposal's majority of the minority-approach see Holger Fleischer, Related Party Transactions bei börsennotierten Gesellschaften: Deutsches Aktien(konzern)recht und Europäische Reformvorschläge, 69 BETRIEBS-BERATER [BB] 2691 (2014); Dirk Zetzsche, Langfristigkeit im Aktienrecht? - Der Vorschlag der Kommission zur Reform der Aktionärsrechterichtlinie, 17 NEUE ZEITSCHRIFT FÜR GESELLSCHAFTSRECHT [NZG] 1121 1126-8 (2014); Rachid René Wiersch, Der Richtlinienentwurf zu Transaktionen mit nahestehenden Unternehmen und Personen, 17 NZG 1131, 1135-6 (2014).

${ }^{6}$ Commission Proposal for a Directive of the European Parliament and of the Council amending Directive 2007/36/EC as regards the encouragement of long-term shareholder engagement and Directive 2013/34/EU as regards certain elements of the corporate governance statement, art. 9c, COM (2014) 213 final (Apr. 9, 2014).

${ }^{7}$ The main feature of the original proposal was a mandatory ratification of significant related party transactions by outside shareholders after full disclosure and independent fairness assessment, for a discussion see Tobias H. Tröger, Corporate Groups, in GERMAN AND NORDIC PERSPECTIVES ON COMPANY LAW AND CAPITAL MARKETS LAW 157, 182-92 (Holger Fleischer, Jesper Lau Hansen \& Wolf-Georg Ringe eds., 2015). The final compromise in the legislative process makes both the thirdparty fairness assessment and the disinterested minority approval optional and declares it sufficient that the fairness assessment as well as the consent is given by the administrative or supervisory body instead, if the related party cannot take advantage of its dominant position in the procedure, see Directive (EU) 2017/828 of the European Parliament and of the Council of 17 May 2017 amending Directive 2007/36/EC as regards the encouragement of long-term shareholder engagement art. 1(4) O.J. (L 132) 1, which introduces the new art. 9c into Directive 2007/36/EC of the European Parliament and of the Council of 11 July 2007 on the exercise of certain rights of shareholders in listed companies, 2007 O.J. (L 184) 17.

${ }^{8}$ Many German commentators, particular corporate counsel, centered their critique of the original Commission proposal on an alleged neglect of the German two-tier system, see for instance Christoph H. Seibt, Regulierung von Transaktionen mit nahestehenden Personen und Unternehmen durch den Vorschlag der Europäischen Kommission zur Revision der Aktionärsrechterichtlinie - Zusätzliche Vorabinformationen und Geschäftsführung durch die Hauptversammlung?, in ERFORDERLICHE HARMONISIERUNG ODER UNNÖTIGER SYSTEMBRUCH - DER VORSCHLAG DER EU-KOMMISSION ZU RELATED PARTY TRANSACTIONS 6, 24 (Bundesverband der deutschen Industrie ed., 2014); Jochen Vetter, Regelungsbedarf bei "Related Party Transactions", 179 ZEITSCHRIFT FÜR DAS GESAMTE HANDELS- UND WIRTSCHAFTSRECHT [ZHR] 273, 305--6 (2015). 
that better explains the proclivity of policy makers, corporate stakeholders and also practically oriented legal scholars to look more favorably at a system that is rather hospitable to transacting with (certain) controllers. ${ }^{9}$ However, this paper also makes the point that a reorientation of banks' business models removed a key component from the institutional setting, which destroys the basis for the claims to maintain a proven and tested regime.

To be sure, German corporate law does not, and never did neglect minority protection outright. ${ }^{10}$ Yet, at first sight, it relies on rather idiosyncratic institutions, a codified law of corporate groups in particular, ${ }^{11}$ to implement the objectives that are widely shared across jurisdictions. ${ }^{12}$ After all, the conflict between incumbent blockholders and outside investors is identical at the outset across jurisdictions. ${ }^{13}$ What is it then that explains Germany's reluctance to regulate related party transactions head on? If institutional frameworks differ in a way that influences economic results, ${ }^{14}$ one plausible explanation relates to a sustained divergence in the payouts that (minority) shareholders and/or stakeholders receive in various jurisdictions. Obviously, such differences influence the political diagram of forces that shapes corporate law. More

${ }^{9}$ Although the standard definition, particularly for accounting purposes, is much broader and also involves management, see for instance International Accounting Standards [IAS] 24(9), this chapter looks only at transactions that involve a significant shareholder.

${ }^{10} \mathrm{~A}$ comparative survey even purports that German corporate law addresses the vertical agency conflict between majority and minority shareholders much more prominently - which is not equivalent to saying more effectively - than U.S. law which is understandable given the respective ownership patterns, Theodor Baums \& Kenneth E. Scott, Taking Shareholder Protection Seriously? Corporate Governance in the United States and Germany, 53 AM. J. COMP. L. 31, 40 (2005).

${ }^{11}$ On the very few jurisdictions that follow the German approach (Portugal, Brazil, Croatia, Slovenia and Albania), or at least adapted it for a while (Hungary and the Czech Republic), see European Model Company Act (EMCA), Ch. 16, Introduction, at 3-4, http://law.au.dk/fileadmin/Jura/dokumenter/CHAPTER_16_GROUPS_OF_COMPANIES.pdf (Oct. 10, 2013); Klaus J. Hopt, Comparative Corporate Governance: The State of the Art and International Regulation, 59 AM. J. COMP. L. 1, 45 (2011). For recent advances by some of Europe's most prominent corporate law scholars to revive an enlightened idea of dealing with corporate groups in a specific body of corporate law see also Peter Böckli et al., A Proposal for the Reform of Group Law in Europe, 18 EUR. BUS. ORG. L. REV. 1-49 (2017).

${ }^{12}$ For a comparative survey that classifies German law as a (flawed) variation of a widespread, standard-based approach see Tröger supra note 7 at 177-181.

${ }^{13}$ For functional descriptions see Mark J. Roe, The Institutions of Corporate Governance, in HANDBOOK OF NEW InSTITUTIONAL ECONOMICS 371, $372-5$ (Claude Ménard \& Mary M. Shirley eds., 2008); John Armour, Henry Hansmann \& Reinier Kraakman, Agency Problems and Legal Strategies, in THE ANATOMY OF CORPORATE LAW 35, 36 (Reinier Kraakman et al. eds., 2d ed. 2009).

${ }^{14}$ The limited empirical evidence indicates that private benefits of control vary across jurisdictions, see Tatiana Nenova, The value of corporate voting rights and control: A cross-county analysis, 68 J. FIN. ECON. 325 (2003) (finding in 1997 the value of voting blocks that conferred control in a crosscountry sample of 661 firms with dual-class stock to be positive and above the value of the U.S. observations (near zero) in the surveyed continental European jurisdictions, with the notable exceptions of Denmark and Finland); Alexander Dyck \& Luigi Zingales, Private Benefits of Control: An International Comparison, 59 J. FIN. 537, 551 (2004) (showing in a sample of 393 sale of control transactions that occurred in 39 countries between 1990 and 2000 control premiums in continental Europe to be generally positive, frequently above the sample-median - although not in Germany - and in all surveyed jurisdictions higher than the U.S.-median). 
specifically, if German minority shareholders and other stakeholders received compensating benefits that are larger than in other jurisdictions they might rationally accept more tunneling and endorse institutions that allow it in adequate degree. Under these preconditions, the consumption of private benefits of control can be understood as a reward for the creation of additional value by controllers. In that sense, the explanation identifies a real world example of the normative recommendation put forward in the strand of literature that argues for permitting an optimal level of controller rent seeking. ${ }^{15}$

To make this point, this chapter sketches briefly the main features of Germany Inc. as a dense corporate network centered around a few financial institutions (infra 2). It continues by highlighting key aspects of German corporate law that have a bearing on related party transactions. The most important institutions like capital maintenance rules and substantive standards against tunneling (duty of loyalty-type obligations in group law) equip interested insiders with firm-specific knowledge and business acumen with powerful tools to curb rent-seeking by both management and blockholders. Within the network, the legal remedies mainly served as a backdrop against which informal enforcement occurred. The very same institutions of corporate governance, however, prove powerless in the hands of dispersed shareholders who are remote from the firm and do not possess relevant information. Hence, non-controlling equity-holders were in no position to limit the rent-extraction by certain insiders in a meaningful way. This is particularly true because already in the 1930s an amendment to the German Stock Corporation Act scraped the fragments of a majority-of-the-minority rule that could have served to empower dispersed shareholders. The chapter synthesizes the observations by showing that the key objectives of the peculiar industrial organization in Germany would not have been achieved in a corporate and securities law environment that strengthened the role of un-coordinated portfolio investors (infra 3). In an outlook, it argues that with the dismantling of Germany Inc. and an increasingly more international shareholder base, the resistance to a meaningful restriction of related party transactions has not only lost its justification, because the idiosyncratic valuecreating function of certain blockholders has largely disappeared, but leaves a potentially harmful void. In fact, with the constraints historically put on dominant shareholder rent-seeking gone, more detrimental forms of tunneling can now occur and are insufficiently restricted by alternative institutional arrangements (infra 4). Finally, the chapter concludes with a summary (infra ).

\section{Main features of Germany InC.}

${ }^{15}$ See Ronald J. Gilson \& Alan Schwartz, Corporate Control and Credible Commitment, 43 INT'L REV. L. ECON. 119, 122-3 (2015) (presenting a stylized model to show that controllers' beneficial efforts to increase firm value are optimal if they can commit to consuming only a pre-specified share of private benefits); Maria Gutiérrez \& Maria Isabel Sáez, A Contractual Approach to Discipline SelfDealing by Controlling Shareholders, 2 J. L. FIN. ACC'T. 173, 176-7 (2017) (showing that social benefits resulting from investment efficiency can be maximized if some degree of private benefits can be consumed). 
This part recalls the well-known characteristics of Germany Inc. that also determine the normative stance vis-à-vis related party transactions (2.1). It shows that the key objectives of the German coordinated industrial organization entail a generally positive evaluation of certain related party transactions across the decades that — at the margin - militates in favor of a relatively unfettered sphere for conducting such transactions (2.2).

\subsection{NETWORK CHARACTERISTICS AND DEVELOPMENT}

With regard to this chapter's focus, the main characteristics of Germany Inc. lie in the significant shareholdings of financial institutions (banks, insurance companies) in industrial firms and the pervasive overlaps in management personnel in most major German corporations. ${ }^{16}$ The extensive and encompassing network that interlocked all major players of the German economy distinguishes this form of industrial organization from others with network features, like for instance the Japanese keiretsu-system, which was characterized by isolated conglomerates. ${ }^{17}$ The quasi-cartelized organization of the German industry protected at least the core of the network against external influence and competition and made the interests of these central participants much more dependent on the performance of the wider economy than on that of individual firms. The returns Germany Inc.'s key players generated through their investment activities, broadly understood (see infra 2.2), hinged critically on sustaining an overall favorable economic

${ }^{16}$ For descriptions see for instance Rolf Ziegler, Donald Bender \& Hermann Biehler, Industry and Banking in the German Corporate Network, in NETWORKS OF CORPORATE POWER 91 (Frans N. Stokman, Rolf Ziegler \& John Scott eds., 1984); Paul Windolf \& Jürgen Beyer, Co-operative capitalism: corporate networks in Germany and Britain, 47 BRITISH J. SOC. 205 (1996); JÜRGEN BEYER, MANAGERHERRSCHAFT IN DEUTSCHLAND? 'CORPORATE GOVERNANCE' UNTER VERFLECHTUNGSBEDINGUNGEN 120-181 (1998); for a highly illustrative visualization see Martin Höpner \& Lothar Krempel, The Politics of the German Company Network, 8 COMP. \& CHANGE 339, 340 (2004); for a comparative survey see Paul Windolf and Michael Nollert, Institutionen, Interessen, Netwerke. Unternehmensverflechtungen im internationalen Vergleich [Institutions, Interests, and Corporate Networks. A Comparative Analysis], 42 POLITISCHE VIERTELJAHRESSCHRIFT (PVS) 51, 56-73 (2001) (describing key characteristics of corporate networks in six market economies). See also Ralf Elsas \& Jan Pieter Krahnen, Universal Banks and Relationships with Firms, in THE GERMAN FINANCIAL SYSTEM 197, 199-207 (Jan Pieter Krahnen \& Reinhard H. Schmidt eds., 2004) (showing that the specific role of banks in the network was limited to the relationship with Germany's largest public firms).

${ }^{17}$ On the structure of the prototypic keiretsu see for instance Paul Sheard, The Main Bank System and Corporate Monitoring and Control in Japan, 11 J. ECON. BEHAV. \& ORG. 399, 401-3 (1989); Ronald J. Gilson \& Mark J. Roe, Understanding the Japanese Keiretsu: Overlaps Between Corporate Governance and Industrial Organization, 102 YALE L.J. 871, 879 (1993); for an alternative interpretation see Yoshiro Miwa \& Mark Ramseyer, The Fable of the Keiretsu, 11 J. ECON. \& MGMT. STRATEGY 169 (2002) (arguing that key characteristics of the lending relationship with the main banks do not support the idea of these institutions being monopoly providers of capital).

In Italy, Mediobanca consciously created in 1946 as an investment bank to facilitate the reorganization of the war-damaged economy also played a strong coordinating role through its longtime CEO, Enrico Cuccia, and clustering together significant shareholdings in many Northern Italian firms (the "Northern Galaxy"), yet without creating a network as dense as Germany Inc., particularly because the banking system remained highly decentralized, for a description see Richard Deeg, Remaking Italian Capitalism? The Politics of Corporate Governance Reform, 28 W. EUR. POL. 521, 526-7 (2005). 
situation. ${ }^{18}$ Revenues of individual firms in relation to others were clearly less relevant for these players. With due variations, they acted like portfolio investors with diversified positions that made investment success a function of an optimized beta instead of an asset specific alpha, ${ }^{19}$ because maximizing individual firm value would create negative externalities for other portfolio firms.

This common macro-economic orientation was a hallmark feature of Germany Inc. at all times. Of course, this continuous feature coincided with diverging political interests and thus served varying social purposes through the ages. ${ }^{20}$ Moreover, despite the manifest interests of social planners, Germany Inc. was not entirely the result of a designed order: many equity holdings of banks emerged out of unsuccessful share offerings in which banks acted as firm underwriters or as a result of corporate reorganizations with debt-equity-swaps. ${ }^{21}$ However, even the accidental parts of its development ultimately only added to the stability of the German form of industrial organization.

The key aspect is that the network that put profit-seeking financial institutions at the center could only survive if these institutions generated sufficient profits from their activity.

${ }^{18}$ Wolf-Georg Ringe, Changing Law and Ownership Patterns in Germany, 63 AM. J. COMP. L. 493, 501 (2015).

${ }^{19}$ In investment theory, beta is a measure of volatility, for instance how a portfolio develops in relation to a market-index (correlation), whereas alpha describes the actual return of an investment in relation to the risk-adjusted expected return of the respective asset, see for instance ZVI BODIE, ALEX KANE \& ALAN J. MARCUS, INVESTMENTS AND PORTFOLIO MANAGEMENT 259-68 (10th ed. 2014).

${ }^{20}$ For a survey of the socio-economic and political forces that supported (and unsuccessfully opposed) Germany Inc. during the Imperial area (1871-1918), the Weimar Republic (1918-1933), the Nazi dictatorship (1933-1945) and the Federal Republic (since 1949) see Höpner \& Krempel supra note 16 , at 341-8.

${ }^{21}$ Höpner \& Krempel supra note 16, at 342 (share offerings) and 343 (conversion of non-performing loans into long-term industrial shareholdings); for a case study of a typical going-public transaction in which the underwriter (voluntarily) retained a fraction of the newly issued shares, HANS OTTO EGLAU, WIE GOTT IN FRANKFURT 20 (1989). Similarly for the acquisition of a majority block in car manufacturer Mercedes-Benz as a result of a corporate reorganization, Hans E. Büschgen, Die Deutsche Bank von 1957 bis zur Gegenwart: Aufstieg zum internationalen Finanzdienstleistungskonzern, in DIE DEUTSCHE BANK 1870-1995 579, 657 (Lothar Gall et al. eds., 1995). 
The more optimistic view is that banks and insurance companies acted like engaged shareholders who monitored management to the benefit of all shareholders, ${ }^{22}$ while a more skeptical position hints at a rent-seeking use of blockholder power ${ }^{23}$ by German financial institutions. ${ }^{24}$

In principle, this chapter's interpretation reconciles the conflicting views to some degree and draws important inferences from this insight: some of the rent-seeking behavior of financial institutions in Germany Inc. can be understood as a necessary and tacitly consented compensation for these institutions' active corporate governance involvement. Therefore, the institutions of corporate governance that have a bearing on related party transactions were designed in a way that on the one hand bolstered financial institutions' monitoring function but also facilitated at least some degree of tunneling. Obviously, no claim as to the overall efficiency of this regime can be made without thorough empirical investigation. Yet such an overall welfare assessment is unnecessary with a view to this chapter's narrower purpose to enhance our understanding of the role of related party transactions and the legal regime that governed them in Germany Inc. and the consequences these insights entail after the dismantling of this idiosyncratic interfirm network.

\subsection{GERMANY INC. AND RELATED PARTY TRANSACTIONS}

Earlier research indicates not only that bank influence had a positive effect on the value of German firms, but also that this creation of value was larger than that of concentrated ownership

${ }^{22}$ Joseph A. Grundfest, Subordination of American Capital, 27 J. FIN. ECON. 89, 105 (1990); Michael E. Porter, Capital Choices: changing the way America invests in industry, 5 J. APPLIED CORP. FIN. 4 (1992).

${ }^{23}$ The voting power of German banks was not derived only from their own shareholdings but also from the proxies that they could exercise for the shares they kept as custodians for their customers, see for instance Jeremy Edwards \& Marcus Nibler, Corporate governance in Germany: The role of banks and ownership concentration“, 32 ECON. POL'Y 239 (2000) (finding in a sample of German industrial and service firms that banks could on average exercise $8.5 \%$ of the voting rights via proxies in addition to the $6.7 \%$ accruing from their own equity stakes). Traditionally, the voting power conferred on banks by own equity holdings and proxies was amplified by voting caps that could be stipulated in the charter and applied to blockholders, see Aktiengesetz [AktG] [Stock Corporation Act], Sept. 6, 1965, BGB1. I at 1089, § 134(1) (Ger.). Large blockholders were barred from exercising their full voting power while banks who acted on behalf of small shareholders were unrestricted in aggregating votes. Finally, equity ownership and proxy voting of custodial shares was concentrated in a few large banks. This suggests that some coordinated behavior aligned even those votes that were cast by different institutions within this group, Gary Gorton \& Frank A. Schmid, Universal banking and the performance of German firms, 58 J. FIN. 29, 46 (2000) see also Arno Gottschalk, Der Stimmrechtseinfluss der Banken in der Aktionärsversammlung der Großunternehmen, 41 ZEITSCHRIFT DES WIRTSCHAFTS- UND SOZIALWISSENSCHAFTLICHEN INSTITUTS DER HANS-BÖCKLER-STIFTUNG [WSI-MITTEILUNGEN] 294, 302-3 (1988) (purporting that the group of the largest financial institutions even controlled their own general meetings as a result of pooled proxies).

${ }^{24}$ Ekkehard Wenger \& Christoph Kaserer, The German system of corporate governance - a model that should no be imitated, in COMPETITION AND CONVERGENCE IN FINANCIAL MARKETS 41, 50 (Stanley W. Black \& Mathias Moersch eds., 1998). For a similar assessment of the Japanese main bank in a keiretsu see David E. Weinstein \& Yishay Yafeh, On the Costs of A Bank-Centered Financial System: Evidence From the Changing Main Bank Relations in Japan, 53 J. Fin. 635 (1998). 
with the delta being statistically significant. ${ }^{25}$ This seems to rebut the hypothesis that banks used their influence to extract value from corporations. Instead they served as effective monitors of managerial ${ }^{26}$ and/or (non-bank) blockholder opportunism. ${ }^{27}$ In a sense, the key financial institutions functioned like the frequently dreamt-up managers of diversified portfolios actively engaged in firms' corporate governance. ${ }^{28}$

${ }^{25}$ Gorton \& Schmid supra note 23 at 57-66 (surveying cross-sections of public and private German firms for the period between 1975 and 1986). For similar results albeit achieved with a much smaller dataset and less sophisticated methodology see John R. Cable, Capital Market Information and Industrial Performance: The Role of West German Banks, 95 ECON. J. 118 (1985); for a different view from a historical perspective see Caroline M. Fohlin, Relationship Banking, Liquidity, and Investment in the German Industrialization, 53 J. FIN. 1737, 1755 (1998).

${ }^{26}$ Legal institutions are frequently perceived as inept to curb managerial opportunism, which dominant shareholders can effectively confine, see for instance Mark J. Roe, Corporate Law's Limits, 31 J. LEGAL STUD. 233, 239-40 (showing that mainly the business judgement rule insulates managers from law's reach). There is early evidence from the U.S. that the existence of concentrated ownership curbs managerial rent-seeking and improves firm performance where horizontal agency conflicts are the key challenge for corporate governance, see for instance Harold Demsetz \& Kenneth Lehn, The Structure of Corporate Ownership: Causes and Consequences, 93 J. POL. ECON. 1155 (1985), Wayne H. Mikkelson \& Richard S. Ruback, An Empirical Analysis of the Interfirm Equity Investment Process, 14 J. FIN. ECON. 523 (1985); Clifford G. Holderness \& Dennis P. Sheehan, The Role of Majority Shareholders in Publicly Held Corporations: An Exploratory Analysis, 20 J. FIN. ECON. 317 (1988); Richard J. Zeckhauser \& John Pound, Are Large Shareholders Effective Monitors? An Investigation of Share Ownership and Corporate Performance, in ASYMMETRIC INFORMATION, CORPORATE FINANCE, AND INVESTMENT 149 (G Hubbard ed., 1990); Michael J. Barclay \& Clifford G. Holderness, Negotiated Block Trades and Corporate Control, 46 J. FIN. 861 (1991).

${ }^{27}$ The existence of large non-bank blockholders besides banks was an important feature of German industrial firms, for numbers see for instance Edwards \& Nibler supra note 23; Julian R. Franks \& Colin P. Mayer, Ownership and Control of German Corporations, 14 REV. FIN. STUD. 943 (2001); Marco Becht \& Ekkehart Boehmer, Ownership and voting power in Germany, in THE CONTROL OF CORPORATE EUROPE 128-153 (Fabrizio Barca \& Marco Becht eds., 2001); Marco Becht \& Ekkehart Boehmer, Voting control in German corporations, 23 INT'L REV. L. \& ECON. 1 (2003). Similar inferences can be drawn from the descriptive statistics presented in the survey of Gorton \& Schmid supra note 23 at 41 . Yet it has to be noted that these non-bank blockholders did not form nodes of the network referred to as Germany Inc. in the narrow sense because they held stakes typically only in one firm, see Mara Faccio \& Larry H.P. Lang, The ultimate ownership of Western European corporations, 65 J. FIN. ECON. 365 (2002) (finding that besides banks, insurance companies and the government, controlling shareholders typically represented (founding) families); Ekkehart Boehmer, Who Controls German Corporations?, in CORPORATE GOVERNANCE REGIMES: CONVERGENCE AND DIVERSITY 268-286 (Joseph A. McCahery et al. (eds.), 2002) (same); Stefan Prigge, A Survey of German Corporate Governance, in COMPARATIVE CORPORATE GOVERnANCE - THE STATE OF THE ART AND EMERGING RESEARCH 943, 974-78 (Klaus J. Hopt et al. (eds), 1998). In particular, cross-shareholdings remained rare in the industrial sector, Höpner \& Krempel supra note 16 at 341.

${ }^{28}$ For early, optimistic accounts that supposed mutual and pension funds could assume such a role in the U.S. see e.g. Bernhard S. Black, Agents Watching Agents: The Promise of Institutional Investor Voice, 39 UCLA L. REV. 811 (1992); John C. Coffee, Jr., Liquidity versus Control: The Institutional Investor as a Corporate Monitor, 91 ColuM. L. REV. 1277 (1991); Roberta Romano, Public Pension Fund Activism in Corporate Governance Reconsidered 93 COLUM. L. REV. 795 (1993); but see also Edward B. Rock, The Logic and (Uncertain) Significance of Institutional Shareholder Activism, 79 GEO. L. J. 445-506 (1991). 
The standard explanation for such an observation is that their cash-flow rights-stemming from both equity claims and lending relations-were sufficiently correlated with firm performance. Banks were thus momentously incentivized to use their clout to improve firm performance. ${ }^{29}$ It is largely irrelevant, whether this incentive effect is a function of a generally upward sloping or a u-shaped relationship between firm performance and voting-based control rights. In the latter case where voting power up to a trough is used to extract private benefits and is only exercised for efficiency enhancing activities beyond this low point, ${ }^{30}$ banks' equity ownership in Germany Inc. must be understood as falling outside the redistributive range. In fact, only a continuously downward sloping relationship, which would indicate a growing wedge between dominant banks' and other equity-holders' distributive interests, seems excluded.

Yet, monitoring is costly and does not only create a free-rider problem in firms with dispersed ownership ${ }^{31}$ but also may break down at the margin if a controller is not reimbursed for the expenses that create a positive externality for other shareholders. ${ }^{32}$ During the heyday of Germany Inc., banks already possessed cash-flow rights in excess of their equity holdings, mainly as a function of their lending operations and underwriter activities. If indeed these operations had been their main source of income, their monitoring activities could have been limited to preventing rent-seeking that imperiled firms' viability, allowing managers or other blockholders to consume large private benefits in the non-perilous zone. ${ }^{33}$ Yet, the extra returns potentially generated in these business lines without rent-seeking behavior (for instance from lower default probabilities of firms that had better governance; higher fees from successful public offerings with lower discounts for looming expropriation risk) were relatively small. ${ }^{34}$ Therefore, they would not necessarily explain the full scope of banks' engagement as key governance players who levered heavily on their combined power as shareholders, lenders, gatekeepers to capital markets, and proxy holders. After all, banks had to refinance themselves and generate profits for their investors. To be sure, capital markets, particularly for banks, were far

${ }^{29}$ On the incentive effect when cash-flow rights and firm performance are highly correlated see generally Michael C. Jensen \& William H. Meckling, Theory of the Firm: Managerial Behavior, Agency Costs, and Ownership Structure, 3 J. FIn. ECON. 305 (1976); Rafael La Porta et al., Investor Protection and Corporate Valuation, 57 J. FIN. 1147 (2002).

${ }^{30}$ The turning point is located where the value of the private benefits that can be extracted is equal to the loss in value that such rent-seeking behavior entails for the shares held by the controller.

${ }^{31}$ Sanford J. Grossman \& Oliver D. Hart, Takeover bids, the free-rider problem, and the theory of the corporation, 11 BELL J. ECON. 42 (1980).

32 The controller can only capture the payoffs from her efforts according to her proportionate cash-flow rights, the remaining fraction being attribute to (passive) beneficiaries, Andrei Shleifer \& Robert M. Vishny, Large Shareholders and Corporate Control, 94 J. POL. ECON. 461, 463 (1986).

${ }^{33}$ It is questionable, whether transactions that threaten a firm's existence are easy to identify $e x$ ante and whether monitoring with a limited objective could indeed be more lenient and less cost-intensive.

${ }^{34}$ Firms related to Germany Inc. mainly financed themselves internally through retained earnings making both bank loans and public offerings subordinated sources of capital, Höpner \& Krempel supra note 16 at 343. 
less competitive than compared to those of today's globalized world. Yet, issuers were in principle still confronted with the well-known competitive disadvantage any portfolio investor incurs vis-à-vis its peers when the active involvement in firm level governance produces costs that are not borne by other shareholders who compete for funds with the active ones. ${ }^{35}$

In fact, it seems more plausible that banks' had their beneficial monitoring function compensated also by consuming private benefits of control, ${ }^{36}$ that is a moderate form of tunneling in related party transactions that rendered monitoring profitable but did not fully eat up the efficiency gains from their involvement in corporate governance. ${ }^{37}$ Frequently the main financial institutions are seen as members of a narrow oligopoly or even cartel who charged inflated prices for their services. ${ }^{38}$ Yet, given their strong role as corporate insiders such market power was arguably unnecessary to reap additional benefits from transactions with clients, regardless of the ability to charge inflated prices market-wide. At least in relation to those clients in which banks' could exercise vote-based influence, they could also set conditions that favored them in related party transactions. Still, the combination of the influence of banks on the governance of individual firms with non-competitive markets for financial services facilitated the extraction of rents. ${ }^{39}$

${ }^{35}$ For the general story with a view to institutional investors see Ronald J. Gilson \& Jeffrey N. Gordon, The Agency Costs of Agency Capitalism: Activist Investors and the Reevaluation of Governance Rights, 113 COLUM. L. REV. 863, 889-95 (2013) (arguing that free-rider problems among asset managers prevent rational institutional portfolio investors like mutual funds, pension funds etc. from engaging in firm-level corporate governance activities).

${ }^{36}$ For an official statement of Bundesbank that hinted at least at the possibility of such tunneling activities of banks see Deutsche Bundesbank, Der Aktienmarkt in der Bundesrepublik Deutschland und seine Entwicklungsmöglichkeiten, MONATSBERICHT DER DEUTSCHEN BUNDESBANK, April 1984, at 12, 16 (reporting a bias in banks' corporate finance advice).

${ }^{37}$ If tunneling had been more extensive, the positive effect of bank involvement on firm value uncovered in Gorton \& Schmid supra note 23 at 57-66 would be inexplicable.

${ }^{38}$ For an important policy report, which by and large subscribes to this view, see BUNDESMINISTERIUM DER FINANZEN, BERICHT DER STUDIENKOMMISSION „GRUNDSATZFRAGEN DER KREDITWIRTSCHAFT“(1979).

${ }^{39}$ For empirical evidence on the anticompetitive effects of the presence of relatively large investors with diversified portfolios see also José Azar, Martin C. Schmalz \& Isabel Tecu, Anti-Competitive Effects on Common Ownership (U. Mich. Ross School of Mgmt. Working Paper No. 1235, 2017), https://ssrn.com/abstract=2427345 (showing that common ownership of competitors by diversified asset managers increases product prices); for indirect evidence revealing the subtle channels of influence see Miguel Antón et al., Common Ownership, Competition, and Top Management Incentives (U. Mich. Ross School of Mgmt. Working Paper No. 1228, 2016), https://ssrn.com/abstract=2802332 (showing that manager remuneration in more commonly owned industries is more geared to competing firm performance than own firm performance); on the underlying theory that shows that value maximization of diversified portfolio investors may deviate from socially optimal profit maximization at the firm level see for instance Anat R. Admati, Paul Pfleiderer \& Josef Zechner, Large shareholder activism, risk sharing, and Financial market equilibrium, 102 J. POL. ECON. 1097, 1112-1116 (1994) (devising a stylized model to show that blockholders may have incentives to monitor in a way that decreases the expected pay-off of a market portfolio); Robert G. Hansen \& John R. Lott, Externalities and Corporate Objectives in a World with Diversified Shareholder/Consumers, 31 J. FIN. \& QUANTITATIVE ANALYSIS 43, 47-50 (1996) (showing that externalities imposed on other portfolio firms drive the preference for 
As a consequence, it can be hypothesized that the institutions of corporate governance that bear on related party transactions in Germany Inc. would not preclude tunneling altogether. However, they would provide a background against which certain players (financial institutions) were able to fend off rent-seeking behavior of management and other shareholders. Under such an institutional arrangement financial institutions could indeed act as self-compensating monitors.

3 MinORity PRotection In GERMAN CORPORATE AND SECURITIES LAWS IN THE CONTEXT OF GERMANY INC.

This paragraph takes a closer look at those parts of German corporate law commonly seen as the main antidotes against tunneling transactions. ${ }^{40}$ It indicates that both the capital maintenance rule (infra 3.1) and the prohibition to act to the detriment of the corporation as codified in the law of corporate groups (infra 3.2) provide a powerful backdrop against which sophisticated shareholders with granular firm-specific information can constrain rent-extraction by management or controlling shareholders. The analysis also shows that both legal restrictions are largely ineffective in the hands of dispersed shareholders who are remote from tainted related party transactions, not least because individual equity holders either lack the legal capacity or the incentives to act in the collective interest of minority shareholders as a class. Hence, the statutory provisions and doctrines at the center of the agency conflict between blockholders and minority shareholders enabled financial institutions at the heart of Germany Inc. to assume a powerful, value-enhancing role as inside-monitors but also to self-compensate for their corporate governance services. The picture is rounded off by a brief look at an amendment of the Stock Corporation Act that removed a key determinant of a workable majority of the minorityrule and thus further facilitated the unrestricted execution of related party transactions between firms and financial institutions (infra 3.3). Finally, this section puts the weak position of uncoordinated small shareholders in German corporate law in the broader context and shows that key objectives of the peculiar industrial organization of Germany Inc. would have been missed, if outside investors had been afforded more meaningful protections (infra 3.4).

\subsection{CAPITAL MAINTENANCE AND THE DOCTRINE OF HIDDEN DISTRIBUTIONS}

corporate objectives of portfolio investors); Amir Rubin, Diversification and Corporate Decisions, 3 CORP. OWNERSHIP P\& CONTROL 209 (2006) (showing which key implementations of the corporate objective function are affected by portfolio diversification).

${ }^{40}$ The contributions to the literature that argued against the E.U. proposal in the recast Shareholder Rights directive (supra note 6) referred indeed primarily to the capital maintenance rule and the law of corporate groups to furnish evidence that German corporate law had sufficient safeguards against related party opportunism, see for instance Tim Drygala, Europäisches Konzernrecht: Gruppeninteresse und Related Party Transactions, 58 DIE AKTIENGESELLSCHAFT [AG] 198, 207-10 (2013); Fleischer supra note 5 at 2696; Christoph H. Seibt, Richtlinienvorschlag zur Weiterentwicklung des europäischen Corporate Governance Rahmen, 67 DER BETRIEB [DB] 1910, 1914-5 (2014); Walter Bayer \& Philipp Selentin, Related Party Transactions: Der neueste EU-Vorschlag im Kontext des deutschen Aktien- und Konzernrechts, 18 NZG 7, 10-11 (2015). 
At least on the books, the rigid duty to maintain the capital of the corporation provides an encompassing prohibition against the consumption of private benefits by controlling shareholders. Today, the basic principle is also prescribed in supranational law, ${ }^{41}$ but the relevant rules in German corporate law predate the European harmonization and were present during the existence of Germany Inc. at all times. ${ }^{42}$ In essence, they prohibit any distribution of corporate assets to shareholders outside of liquidation except for dividend payments. ${ }^{43}$ The concept of distribution is construed in a very flexible manner and also captures transactions that seek to camouflage the transfer of value from the corporation to shareholders. ${ }^{44}$ It thus includes prototypical tunneling transactions like for instance exchanges with skewed transfer prices, ${ }^{45}$ although it is somewhat doubtful whether it also captures the exploitation of corporate opportunities by the controlling shareholders. ${ }^{46}$

However, a relatively high degree of sophistication and access to inside information is required to detect problematic transactions. ${ }^{47}$ Moreover, in case of a breach, it is primarily the corporation that has a remedy against the beneficiary who has to pay back the distribution received. ${ }^{48}$ As a consequence, a suit has to be brought by the management board that acts on behalf of the corporation as original claimant. As a matter of practice, managers will only act against a dominant shareholder if they face motivating sanctions themselves should they remain passive. Generally, the most important deterrent that prevents tunneling transactions from occurring in the first place (or at least correcting them rapidly ex post) is personal liability of managers who execute the hidden distribution. Indeed, managers face such liability because

${ }^{41}$ Directive 2012/30/EU of the European Parliament and of the Council of 25 October 2012 on coordination of safeguards which, for the protection of the interests of members and others, are required by Member States of companies within the meaning of the second paragraph of Article 54 of the Treaty on the Functioning of the European Union, in respect of the formation of public limited liability companies and the maintenance and alteration of their capital, with a view to making such safeguards equivalent art. 17(1), 2012 O.J. (L 315) 74.

42 Already Allgemeines Deutsches HandelsgesetzBuch [ADHGB] [COMMERCIAL CODE], Apr. 16, 1871, REICHSGESETZBLATT [RGBL.] 63, arts. 216, 217 contained respective provisions that were developed into the contemporary institution by Aktiengesetz [AktG 1937] [Stock Corporation Act 1937], Jan. 30, 1937, RGBL. 107, §§ 52, 54.

${ }^{43} \mathrm{AktG} \S 57(1)$ and (3). For an astute discussion based on finance theory, see PHILIPP SCHEIBENPFLUG, VERHALTENSRISIKEN UND AKTIENRECHTLICHE VERMÖGENSBINDUNG (2016).

${ }^{44}$ For a short sketch of the doctrine see Holger Fleischer, Disguised Distributions and Capital Maintenance in European Company Law, in LEGAL CAPITAL IN EuROPE 94, 95-7 (Marcus Lutter ed., 2007). For an extensive discussion in a standard commentary see Tim Drygala, $\$ 57$ paras 37-94, in KÖLNER KOMMENTAR ZUM AKTIENGESETZ [COLOGNE COMMENTARY ON THE STOCK CORPORATION ACT] (Wolfgang Zöllner \& Ulrich Noack eds., 3d ed. 2011).

${ }^{45}$ See for instance Johnston et al. supra note 3 at 24-6.

${ }^{46}$ For a discussion see TILMANN BEZZENBERgER, DAS KAPITAL DER AKTIENGESELlSCHAFT [THE LEGAL CAPITAL OF STOCK CORPORATIONS] 225 (2005); Drygala supra note 45 at para 58;

${ }^{47}$ On the ex post reporting obligations under IAS 24(18) see Tröger supra note 7 at 176-7.

${ }^{48} \mathrm{AktG} \S 62(1)$. Individual creditors can also sue, yet only if their claims are not settled; in insolvency proceedings only the receiver can act on behalf of the creditors, AktG § 62(2). 
any wrongful distribution automatically constitutes a violation of directors' duties ${ }^{49}$ and negligence on behalf of the directors is generally presumed. ${ }^{50}$ Yet, the directors owe their duties to the corporation. Hence, the corporation is the original claimholder also in director liability cases. ${ }^{51}$ The supervisory board is supposed to act on behalf of the corporation vis-à-vis the management board, ${ }^{52}$ but it has a well-known general tendency to enforce directors' liability only reluctantly if it was somehow involved in the breach and thus potentially faces liability itself. ${ }^{53}$ This proclivity should be even stronger where the supervisory board has to turn directly against a dominant shareholder who is responsible for appointing and removing the members of the supervisory board. ${ }^{54}$ Individual shareholders have no standing to bring a derivative suit. Only a significant minority of shareholders could bring such a suit ${ }^{55}$ but the frequently amended right constituted dead-law at all times. ${ }^{56}$

In sum, the prohibition on distributions only works, if a powerful agent who has sufficient expertise and firm-level information is present besides the controller (related party) and can credibly threaten to take legal actions as a last resort. Hence, banks could police corporate transactions in the shadow of the legal framework despite the fact that they rarely if ever took recourse to legal action outside of insolvency. However, for obvious reasons, outside shareholders could not constrain blockholders in a similarly meaningful way.

\subsection{PROHIBITION TO ACT TO THE DETRIMENT OF THE CORPORATION IN CORPORATE GROUP LAW}

Another body of law that bears immediately on transactions with controlling shareholders is the codified law for corporate groups. ${ }^{57}$ The focus of the discussion in this regard should be on the

${ }^{49}$ AktG § 93(3)(1), frequently, the violation is thus vividly characterized as ,mortal sin“, see for instance Holger Fleischer, Tatbestandsvoraussetzungen der Binnenhaftung [Preconditions of Internal Liability], in HANDBUCH DES VORSTANDSRECHTS [HANDBOOK ON THE LAW OF DIRECTORS] § 11 para 78 (Holger Fleischer ed., 2006).

${ }^{50}$ AktG $\S 93(2)(2)$.

${ }^{51}$ This result is explicitly stated in AktG $\S 93(2)(1)$.

${ }^{52}$ AktG $§ 112$

${ }^{53}$ For a famous description of the problem characterized as a "repression to bite" ("Bisssperre") see Martin Peltzer, Die Haftung des Aufsichtsrats bei Verletzung der Überwachungspflicht, 35 WERTPAPIER-MitTEILUNGEN [WM] 346, 348-9 (1981); see also Mathias Habersack, Perspektiven der aktienrechtlichen Organhaftung, 177 ZEITSCHRIFT FÜR DAS GESAMTE HANDELS- UND WIRTSCHAFTSRECHT [ZHR] 782, 785-6 (2013); Gerhard Wagner, Organhaftung im Interesse der Verhaltenssteuerung, 178 ZHR 227, 239-40 (2014).

${ }^{54} \mathrm{On}$ the appointment and removal rights of dominant shareholders see also infra note 60 .

${ }^{55}$ See today AktG $\S 148$. For a discussion of the various amendments see Oliver Rieckers \& Jochen Vetter, $\$ 148$ paras $26-42$, in KÖLNER KOMMENTAR ZUM AKTIENGESETZ [COLOGNE COMMENTARY ON THE STOCK CORPORATION ACT] (Wolfgang Zöllner \& Ulrich Noack eds., 3d ed. 2015).

${ }^{56}$ Klaus Ulrich Schmolke, Die Aktionärsklage nach $\$ 148$ AktG - Anreizwirkungen de lege lata und Reformanregungen de lege ferenda, 40 ZEITSCHRIFT FÜR UNTERNEHMENS UND GESELLSCHAFTSRECHT [ZGR] 398, 402-3 (2011); Brigitte Haar \& Kristoffel Grechenig, Minderheitenquorum und Mehrheitsmacht bei der Aktionärsklage, 58 AG 653, 654-5 (2013).

${ }^{57}$ For comprehensive accounts see e.g. MATHIAS HABERSACK \& VOLKER EMMERICH, AKTIENUND GMBH-KONZERNRECHT [THE LAW OF CORPORATE GROUPS INVOLVING STOCK CORPORATIONS 
law for those groups in which control is based exclusively on share-ownership, that is, the dominant position of the blockholder is not consolidated by a specific contract. The reason for this focus is that AktG $\S \S 291$ et seq., which govern groups consolidated by a contract of domination ("Beherrschungsvertrag"), provide for a presumably effective sell-out rule. In principle, minority shareholders can sell their stakes at fair value, which effectively thwarts redistributive blockholder strategies that rely on the expropriation of remaining outside shareholders. ${ }^{58}$ However, the sell-out right occurs at a very late stage in the process of group integration. Typically, controlling shareholders conclude contracts of domination only when some time has elapsed after the acquisition of their stake. Therefore, the sell-out right only kicks-in when the value of the firm may already be depressed, because controlling shareholders engaged in tunneling transactions or other rent-seeking activities in the meantime. Hence, to make the sell-out right (appraisal remedy) effective, constraints on related party transaction at earlier stages of the group integration are essential, also because controllers may not strive to consolidate their position by a contract of domination at all.

This section briefly sketches the main content of the respective provisions (infra 3.2.1) in order to evaluate their effectiveness with a particular view to the situation in Germany Inc. (infra 3.2.2).

\subsubsection{MAIN CONTENT}

AND LIMITED LIABILITY CORPORATIONS] 17-774 (8th ed. 2016); Hans-Georg Koppensteiner, $\$ \S 15-22$; $\$$ 291-327, in KÖLNER KOMMENTAR ZUM AKTIENGESETZ [COLOGNE COMMENTARY ON THE STOCK CORPORATION ACT] (Wolfgang Zöllner \& Ulrich Noack eds., 3d ed., 2004); VOLKER EMMERICH \& MATHIAS HABERSACK, KONZERNRECHT [THE LAW OF CORPORATE GROUPS] 26-99, 153-527 (13th ed., 2013); for a concise overview see KARSTEN SCHMIDT, GESELLSCHAFTSRECHT [CORPORATE LAW] 93470 (4th ed. 2002). For delineations in English see e.g. Herbert Wiedemann, The German Experience with the Law of Affiliated Enterprises, in GROUPS OF COMPANIES IN EUROPEAN LAWS 21-43 (Klaus J. Hopt ed. 1982); Klaus Böhlhoff \& Julius Budde, Company Groups - The EEC Proposal for a Ninth Directive in the Light of the Legal Situation in the Federal Republic of Germany, 6 J. CoMP. Bus. \& CAPITAL MKT. L. 163, 164-70 (1984); Peter Hommelhoff, Protection of Minority Shareholders, Investors and Creditors in Corporate Groups: The Strengths and Weaknesses of German Corporate Group Law, 2 EUR. BUS. ORG. L. REV. 61-80 (2001).

${ }^{58}$ For the seminal model see Bebchuk supra note 2 at 971 (showing that the requirement to acquire all shares precludes inefficient control transactions). 
If the parent firm's ${ }^{59}$ control is based on the ownership of shares vested with voting rights, ${ }^{60}$ an arrangement frequently referred to as de facto-group by German courts and commentators, ${ }^{61}$ AktG $\S 311$ prohibits the controlling shareholder from inducing measures that disadvantage the subsidiary without providing full compensation within a year.

First, the practical impact of the provision depends critically on the interpretation of its element 'disadvantage'. The latter is construed to encompass any decrease of or specific risk to the corporation's financial situation or earning position that occurs as a result of the controlling corporation's influence. ${ }^{62}$ Proof of this influence requires a showing that a reasonable and diligent manager of an independent corporation under the circumstances would have behaved differently. ${ }^{63}$

Second, the effectiveness of the prohibition hinges also on what constitutes an eligible compensation that has to be provided during the year. The BGH recently ruled that if the disadvantage shows on the balance sheet, the compensation has to be of a kind that vice versa allows its reporting in accordance with applicable accounting standards. ${ }^{64}$ If disadvantages are not (immediately) reflected on the balance sheet, the majority view in the literature - absent relevant case law-holds that proper compensation presupposes granting an advantage that is

${ }^{59}$ The Federal Court of Justice has consistently held that a controlling firm within the meaning of the law can be any shareholder, regardless of legal form, who pursues economic interests also outside the controlled corporation, Bundesgerichtshof [BGH] [Federal Court of Justice] Oct 13, 1977, 69 Entscheidungen des Bundesgerichtshofs in Zivilsachen [BGHZ] 334 (335 et seq.); BGH May 8, 1979, 74 BGHZ 359 (365); BGH Apr. 22, 1991, 114 BGHZ 203 (213); BGH Mar. 19, 1993, 122 BGHZ 123 (127).

${ }^{60}$ A blockholder who has the majority of votes in the corporation's general meeting can fill at least one half of the seats of the supervisory board, with the other half-or, depending on co-determination laws, a smaller proportion or no seats at all-reserved for labor representatives, AktG, § 111(1). The supervisory board appoints the members of the management board, AktG, § 84(1); co-determination laws ensure that in a tied ballot shareholder representatives will prevail even under equal representation, because the chairman who will usually be a shareholder representative will have a casting vote, $c f$. Gesetz über die Mitbestimmung der Arbeitnehmer [MitbestG] [Act on Employee Co-determination], May 4, 1976, BGBl. I at 1153 as amended, § 29(1)(1). This dominant role in appointment procedures should give majority blockholders significant influence also over the corporation's operations, because board members whose fate depends in large part on the benevolence of the controlling shareholder will typically respond to her suggestions.

${ }^{61}$ See for instance BGH Feb. 15, 1982, 83 BGHZ 122 (137); Ernst Geßler, Der Schutz vor Fremdeinflüssen im Aktienrecht [Protection Against External Influence in Stock Corporation Law], 145 ZHR 457, 457 (1981). The terminology seems suggestive that controlling influence within the meaning of the law can also be based on other means than share-ownership (e.g. key credit or supply relationships). Yet, it only signifies that group integration is not consolidated by contract, and thus does not contradict the notion that the concept of control in AktG $\S 17$ requires at all events an equity stake of the controlling firm, $c f$. BGH Mar. 26, 1984, 90 BGHZ 381 (395-6).

${ }^{62}$ BGH Mar. 1, 1999, 141 BGHZ 80 (84); BGH Dec. 12, 2008, 179 BGHZ 71 para 8; BGH May 19, 2011, 190 BGHZ 7 para 37.

${ }^{63}$ BGH Mar. 1, 1999, 141 BGHZ 80 (88-9); BGH Mar. 3, 2008, 175 BGHZ 365 para 9, 11; BGH Dec. 12, 2008, 179 BGHZ 71 para 9, 10.

${ }^{64}$ BGH June 26, 2012, 15 NZG 1030 para 23 (2012). 
appraisable, though not necessarily reportable. ${ }^{65}$ Hence, non-quantifiable advantages that may be associated with the group-affiliation as such do not qualify.

Quite importantly, if the controlling firm fails to provide for timely compensation it is liable for damages to the controlled corporation jointly and severally with its representatives that actually induced the adverse measures. ${ }^{66}$ The claims can be brought not only by the controlled corporation's management board but also as a derivative action by its individual shareholders, ${ }^{67}$ and its creditors, although the latter can only sue if the controlled corporation is in default. $^{68}$

\subsubsection{THE LAW OF CORPORATE GROUPS AND GERMANY INC.}

The outlined regime basically takes a protective stance that seeks to limit controlling shareholder's adverse influence and mitigate agency conflicts. Yet, it should not be overlooked that the fundamental duty of loyalty codified in AktG $\S 311(1)$ is considerably modified by the elongated possibility to provide compensation for disadvantages within a year. The deferral can be understood as a privilege that is provided to enable at least loose forms of group integration. ${ }^{6}$ In any case, AktG $\S 311$ presumes that both the exercise of influence and the individual disadvantageous act or omission that it induces can be identified. The latter is also the prerequisite if minority shareholders or creditors seek to bring derivative actions on behalf of the controlled corporation. ${ }^{70}$ At least from the perspective of the controlled corporation-which also has standing as the original plaintiff - the task is somewhat facilitated by the management board's obligation to prepare and submit to audit a special report ("Abhängigkeitsbericht") that covers all transactions with the parent and other group affiliates as well as those transactions induced by the controlling shareholder or executed in her interest, AktG $\S \S 312,313 .^{71}$ The report is

${ }^{65}$ Habersack supra note 57 at $\$ 311$ para 63; Jens Koch, $\$ 311$ para 39, in JENS KoCH \& UwE HÜFFER, AKTIENGESETZ [STOCK CORPORATION ACT] (12th ed. 2016); Holger Altmeppen, $\$ 311$ para 338, 340, in MÜNCHENER KOMMENTAR ZUM AKTIENGESETZ [MUNICH COMMENTARY ON THE STOCK CORPORATION ACT] (Wulf Goette \& Mathias Habersack eds., 4d ed. 2015).

${ }^{66} \mathrm{AktG} \S 317(1)$.

${ }^{67} \mathrm{AktG} \S \S 309(4)(1)(2), 317(5)$.

${ }^{68} \mathrm{AktG} \S \S 309(4)(3), 317(5)$.

${ }^{69}$ For a discussion of the enabling dimension of AktG $\S 311$ et seq. see e.g. PETER O. MÜLBERT, AKTIENGESELLSCHAFT, UNTERNEHMENSGRUPPE UND KAPITALMARKT [STOCK CORPORATION, CORPORATE GROUP, AND CAPITAL MARKET] 280-93; 453-5 (2d ed., 1996); but see also Karsten Schmidt, Konzernunternehmen, Unternehmensgruppe und Konzern-Rechtsverhältnis [Group Affiliates, Corporate Group, and Group Legal Relationship], in: FESTSCHRIFT FÜR MARKUS LUTTER ZUM 70. GEBURTSTAG [FESTSCHRIFT CELEBRATING MARKUS LUTTER's 70TH BIRTHDAY] 1167, 1179-83 (Uwe H. Schneider et al. eds., 2000).

${ }^{70}$ The majority view grants some alleviation when it comes to showing that the disadvantageous measure was induced by the controlling shareholder, $c f$. e.g. Altmeppen supra note $65, \S 311$ para 8794; Habersack supra note $65, \S 311$ para 32-36. This implies, however, that the individual measure can be recognized in the first place.

${ }^{71} \mathrm{AktG} \S 312(1)(2)$ mandates that the report includes performance and consideration of the transactions, the advantages and disadvantages of the other activities and the reasons for engaging in 
reviewed by both independent auditors, AktG $\S 313$, and the supervisory board, AktG $\S$ 314(2)(1). However, only the overall assessments of the involved agents have to be disclosed to shareholders. ${ }^{72}$ Hence, the byzantine reporting and auditing duties do little to help shareholders in identifying critical transactions that could be tackled with shareholder litigation. ${ }^{73}$

For a long time, legal scholars delivered a scathing judgment on the effectiveness of the protection for minority shareholders in groups based on share-ownership. ${ }^{74}$ The main objections related to the possibilities to manipulate the general prohibition to disadvantage the controlled corporation because of the elongated compensation rule and the overly bureaucratic reporting system that lacked transparency and meaningful sanctions. ${ }^{75}$ During the 1990 s a reevaluation of the system was initiated that purported that the reporting system actually worked because the management of controlled corporations could fend off disadvantageous transactions by pointing to the requirement to have them signed-off by independent accountants. ${ }^{76}$ This line of reasoning culminated in an assessment by a leading practitioner at the occasion of the AktG fiftieth anniversary who dignified the law as a great success, albeit without presenting any robust evidence. $^{77}$

In fact, it is quite plausible that once again financial institutions who arguably had access to relevant information and were able to discuss issues with the firm's auditors were indeed in a position to make meaningful use of the law on corporate groups as a stick looming in the back

them. AktG $\S 312(1)(3)$ requires reporting of any paid or pledged compensation for the disadvantages incurred.

${ }^{72}$ The assessment of the management board is part of annual financial reporting, AktG § 312(3). The auditor's final assessment is conveyed to the shareholder meeting in conjunction with the supervisory board's communication of its own results, AktG $\S \S 313(5), 314(2)$.

${ }^{73}$ It is one of the key criticisms of the German codified law on corporate groups that the special reporting system is both costly and largely ineffective due to its adamant secrecy, e.g. Wolfgang Zöllner, Qualifizierte Konzernierung im Aktienrecht [Intensified Group Integration in Stock Corporation Law], in GEDÄCHTNISSCHRIFT FÜR BRIGITTE KNOBBE-KeUK 369, 371 (Wolfgang Schön, ed., 2007). For recent advances that also argued in favor of a more transparent system beyond accounting standards see Holger Fleischer, "Geheime Kommandosache": Ist die Vertraulichkeit des Abhängigkeitsberichts (§ 312 AktG) noch zeitgemäß?, 69 BB 835 (2014); Katja Langenbucher, No Market for Corporate Governance? Related Party Transactions and Shareholder Approval Rights, in FESTSCHRIFT FÜR PETERCHRISTIAN MÜLLER-GRAFF 312 (Cordula Stumpf, Friedemann Kainer \& Christian Baldus eds., 2015).

74 BERNHARD GROßFELD, AKTIENGESELLSCHAFT, UNTERNEHMENSKONZENTRATION UND KLEINAKTIONÄR [STOCK CORPORATION, CONCENTRATION OF ENTERPRISES, AND SMALL SHAREHOLDERS] 218-9 (1968); MONOPOLKOMMISSION, VII. HAUPTGUTACHTEN [VII. MAIN REPORT], BTDrucks. 11/2677, para 842 (July 19, 1988)

${ }^{75}$ For a comprehensive survey see Zöllner supra note 73 at 371.

${ }^{76}$ Peter Hommelhoff, Empfielt es sich, das Recht faktischer Unternehmensverbindungen neu zu regeln?, Gutachten G zum 59. Deutschen Juristentag [Is it advisable to amend the law on corporate groups based on share-ownership?, Report G for the 59th German Jurists' Forum], in Verhandlungen des 59. Deutschen Juristentags [HEARINGS OF THE 59TH GERMAN JURISTS' FORUM] G23 (1992).

77 Jochen Vetter, 50 Jahre Aktienkonzernrecht, in 50 Jahre Aktiengesetz 231, 270 (Holger Fleischer, Jens Koch, Bruno Kropff \& Marcus Lutter eds., 2016) (concluding that after 50 years of practical experience the law on de facto corporate groups was a "major coup" and does not exhibit "glaring mistakes, gaps or shortfalls"). 
when conducting their monitoring function. On the other hand, it is unlikely that the relevant body of law did anything helpful for minority shareholders when it came to tunneling transactions with these financial institutions, among other reasons, because it is questionable whether their influence already rendered them dominant shareholders in the legal sense. ${ }^{78}$

\subsection{CORPORATE LAW REFORM OF 1937}

A tiny amendment of corporate law promulgated by the Stock Corporation Act of 1937 is very much in line with the observation that dispersed outside shareholders did not have constructive legal instruments at their disposal to limit rent-seeking by controllers. Until then, shareholders were precluded from voting on transactions between the corporation and themselves. ${ }^{79}$ It is remarkable that this prohibition, which created a prototypical majority-of-the-minority requirement for those related party transactions that required the consent of the general meeting, ${ }^{80}$ was scrapped for Germany's largest firms - and retained for close corporations, ${ }^{81}$ associations, ${ }^{82}$ and arguably partnerships. ${ }^{83}$

It may well be that the legislator was led by practical considerations that aimed at increasing the maneuvering space for professional management in corporations with widely dispersed shareholders. ${ }^{84}$ Yet, it incidentally also increased the latitude for dominant shareholder

${ }^{78}$ The majority view holds that control as prerequisite for being bound by the specific obligations of the law of corporate groups has to be based on shareownership, see Koppensteiner supra note 57 at $\S 17$ paras 33-70 (discussing various sources of influence over the corporation that do not fall under the law of corporate groups); TOBIAS TRÖGER, TREUPFLICHT IM KONZERNRECHT FIDUCIARY DUTIES IN THE LAW ON CORPORATE GROUPS 7-36(2000) (same).

${ }^{79}$ Handelsgesetzbuch [HGB] [COMMERCIAl Code], May 10, 1897, RGBl. at 219, § 252(3)(2).

${ }^{80}$ Prior to the 1937 overhaul the general meeting had a much broader competence than today: it could resolve on all subjects that were not explicitly withdrawn from its pull by law or the charter; in particular, it could issue directions to the management board, HGB Art. 231 para. 1; for a detailed description see Holger Fleischer, Kompetenzen der Hauptversammlung - eine rechtsgeschichtliche, rechtsdogmatische und rechtsvergleichende Bestandsaufnahme [Competence of the General Meeting a Historical, Doctrinal, and Comparative Survey], in AKTIENRECHT IM WANDEL [CHANGES OF STOCK CORPORATION LAW] paras. 9.6-9.7 (Walter Bayer \& Mathias Habersack, 2007).

${ }^{81}$ Gesetz betreffend die Gesellschaften mit beschränkter Haftung [GmbHG] [Limited Liability Corporations Act], Apr. 20, 1892, RGBL. At 477, § 47 para. 4 sentence 2 (Ger.).

${ }^{82}$ BÜrgerliches GesetzBuCh [BGB] [CIVIL CODE], Aug. 18, 1896, RGBL. at 195 as ammended, $\S 34$ (Ger.).

${ }^{83}$ The BGH held that the prohibitions to vote stipulated for corporations carry over to partnerships, BGH, 15 NZG 625, 626-7 (2015). However, the case did not pertain to a transaction with a shareholder.

${ }^{84}$ For such a view ERNST-JOACHIM MeSTMÄCKER, VERWALTUNG, KONZERNGEWALT UND RECHTE DER AKTIONÄRE 267 (1958); on the general stance of the 1937 reform, which sought to strengthen the competence of the management bodies in relation to the general meeting, inducing one of the architects of the reform to characterize the meeting as a "dethroned king", see Franz Schlegelberger, Über das kommende Aktienrecht, 97 DEUTSCHE JUSTIZ [DJ] 1226, 1228 (1935); for an early critique of the abolition of the voting prohibition in related party transactions see RUDOLF MÜLLERERZBACH, DAS PRIVATE RECHT DER MITGLIEDSCHAFT ALS PRÜFSTEIN EINES KAUSALEN RECHTSDENKENS 225-8 (1948). 
rent-seeking. From today's perspective, the reform is also in a striking contrast to current efforts to increase shareholder involvement in related party transactions. ${ }^{85}$ However, the practical consequences of the reform bolster the hypothesis that the institutional environment of Germany Inc. was hospitable to the self-compensation of financial institutions for their monitoring function.

\subsection{INDUSTRIAL ORGANIZATION AS KEY DETERMINANT FOR A LENIENT APPROACH TO RELATED PARTY TRANSACTIONS IN CORPORATE LAW}

According to the predominant assessment of Germany Inc., financial institutions served as industrial policy centers for the quasi-cartelized large firms (supra 2.1). The engineered longterm macro-economic orientation in this type of coordinated market economy would not have been achievable if the institutional environment had given small shareholders more power to push for profit maximization in each individual firm. ${ }^{86}$ Any coordination function that pursued objectives beyond the respective firm would have been thwarted or at least hindered in this counterfactual scenario. In a sense, the strong role of banks in Germany Inc. required as a prerequisite an underdeveloped regime of investor protection.

Seen from this vantage, the lack of meaningful legal remedies against actions that violated the profit maximization objective of individual firms was supposed to serve the "greater good"87 that, at least incidentally, had the effect of opening up sufficient latitude for key players to have their coordinating and monitoring role compensated from the corporate coffers.

\section{Outlook: THe dismantling of Germany InC.}

The final section of this chapter draws on the analysis of the past to predict the likely outcomes if Germany maintains its dismissive stance vis-à-vis a reformed regulation of related party transactions. It shows that a key player who policed controller behavior in the corporate network has vanished, leaving dispersed shareholders without any meaningful corporate law protection against rent-seeking (infra 4.1). It concludes that existing securities laws and accounting standards are insufficient to address the problem, mainly because of well-known enforcement deficits (infra 4.2).

${ }^{85}$ Apart from the E.U. initiatives (supra notes 6 and 7), mandatory shareholder involvement before the execution of significant related party transactions is part of the UK listing rules, and at list an option for Italian firms with a stock exchange listing that can opt into a similar regime in their charter, Böckli et al. supra note 11 at 22, 23. A majority-of-the-minority rule also exists as a safe harbor in Delaware case law, Kahn v. Lynch Commc'n Sys. (Lynch I), 638 A.2d 1110, 1117 (Del. 1994); see also Bershad v. Curtiss-Wright Corp., 535 A.2d 840, 846 (Del. 1987); Rosenblatt v. Getty Oil Co., 493 A.2d 929, 937 (Del. 1985).

${ }^{86}$ To be sure, broadly diversified, large asset managers may have anti-competitive incentives themselves, see supra note 39 . Yet, this seems to be a second-round effect of investor capitalism rather than its hallmark feature.

${ }^{87}$ Again, whether it did or not is an empirical question not to be answered here. 


\subsection{THE DISAPPEARANCE OF A KEY PLAYER}

There is ample evidence that German banks around the turn of the century reacted to competitive pressure from globally integrated markets by changing their business models. This led them inter alia to sell-off of their stakes in industrial firms. Therefore, they also ceased to act as corporate monitors in Germany Inc. ${ }^{88}$ The main take away is that even if the institutional framework sufficed to control related party transactions adequately in the idiosyncratic setting of Germany Inc., it does no longer do so under the changed circumstances. If no sufficiently informed and incentivized corporate insider exists, dispersed shareholders are by and large left to the defunct institutions of corporate law to curb controllers' rent extraction. The "traditionalist" stance taken by many corporate law scholars, practitioners and policy makers ${ }^{89}$ hence creates an unprecedented void with all negative consequences for capital market development, economic growth and social welfare. It is unlikely, that activist investors will fully fill the gap, even if their overall monitoring function was positive. ${ }^{90}$ The reason for this prediction is that activists typically do not target controlled corporations. ${ }^{91}$ Moreover, they look for large inefficiencies to be corrected by strategic reorientations etc. ${ }^{92}$ Although activist campaigns are not absent in firms with controlling shareholders, ${ }^{93}$ specialist funds are still suboptimal substitutes

${ }^{88}$ See for instance Höpner \& Krempel supra note 16 at 348-53; Ringe supra note 18 at 508-16 (surveying empirical analyses that show an increase in ownership dispersion among German firms).

${ }^{89}$ See supra note 5.

${ }^{90}$ For empirical evidence on the impact of hedge fund-activism in the U.S. see Lucian A. Bebchuk, Alon Brav \& Wie Jiang, The Long-Term Effect of Hedge Fund Activism, 115 COLUM. L. REV. 1085 (2015) (presenting evidence that in a five-year window the effect of activist interventions on firm value is positive); Martijn Cremers et al., Hedge Fund Activism and Long-Term Firm Value (Working Paper, 2015), https://ssrn.com/abstract=2693231 (pointing to a selection bias in earlier studies and finding negative effects of hedge fund interventions when compared to a control group of firms that performed just a poor as targets). The available data for Germany is similarly mixed, see for instance Tilman H. Drerup, Long-Term Effects of Hedge Fund Activism in Germany (Working Paper, 2014), https://ssrn.com/abstract=1718365 (showing in a hand-collected dataset covering transactions between 1999 and 2010 that hedge funds were largely ineffective in affecting German listed firms' behavior and that long term market responses to hedge fund investments were almost non-existent); Denis Schweizer \& Mark Mietzner, Hedge Funds versus Private Equity Funds as Shareholder Activists in Germany Differences in Value Creation, 38 J. Fin. Econ. 181-208 (2014) (showing that only private equity funds are successful in reducing agency costs whereas hedgefunds prove largely ineffective); Wolfgang Bessler et al., The Returns to Hedge Fund Activism in Germany, 21 Eur. Fin. M'gmt 106-147 (2015) (showing that hedge-funds generally increased shareholder value in both the short- and long-term with the effect being attributable to non-aggressive funds).

${ }^{91}$ Brian R. Cheffins \& John Armour, The Past, Present, and Future of Shareholder Activism by Hedge Funds, 37 J. Corp. L. 51, 68-69 (2011); Dionysia Katelouzou, Worldwide Hedge Fund Activism: Dimensions and Legal Determinants, 17 U. Pa. J. Bus. L. 789, 800 (2015);

${ }^{92}$ This is also a function of the high costs of activist campaigns, see Nickolay Gantchev, The Costs of Shareholder Activism: Evidence from a Sequential Decision Model, 107 J. FIN. ECON. 610, 623 (2013) (estimating the costs for U.S. hedge funds that escalate conflicts to the level of proxy fights at U\$ 10.5 million on average).

${ }^{93}$ See for instance Kobi Kastiel, Against All Odds: Hedge Fund Activism in Controlled Companies, 2016 Colum. Bus. L. Rev. 60, 80-85 (showing that between 2005 and 2014 hedge fund activism also targeted U.S. public companies with controlling shareholders to a significant extent); Massimo 
for effective inside monitors, not least because their campaigns have to rely on controllers' reputational concerns ${ }^{94}$ that should be limited to more egregious cases of rent-seeking.

\subsection{Why EXISTING SECURITIES LAWS AND ACCOUNTING STANDARDS ARE NOT ENOUGH}

Finally, neither existing securities laws nor accounting standards will fully substitute for the discontinuance of financial institutions' function in Germany Inc. The mandatory bid rule ${ }^{95}$ as well as the tight transparency requirements for significant holdings, ${ }^{96}$ both today prescribed by E.U. legislation, ${ }^{97}$ establish an equal opportunity rule also in German law. Yet, the latter does not help shareholders where ownership structures are already concentrated and no change of control occurs. Moreover, there is a well-known enforcement deficit regarding German securities regulation, which heavily relies on public enforcement and does not provide for class actions of aggrieved investors. ${ }^{98}$ Similarly, full ex post transparency of related party transactions ${ }^{99}$ is insufficient if shareholders lack meaningful tools to seek redress, although some market discipline may follow from negative cost of capital effects for high-volume tunneling firms.

\section{Conclusion}

Germany Inc. was an idiosyncratic form of industrial organization that put financial institutions at the center. This chapter argues that the consumption of private benefits in related party transactions by these key agents can be understood as a compensation for their coordinating and monitoring function in Germany Inc. As a consequence, legal tools apt to curb tunneling remained weak in Germany from the perspective of outside shareholders. While banks were in a position to use their firm-level knowledge and influence to limit rent-seeking by other related parties, their own behavior was not subject to meaningful controls. With the dismantling of

Belcredi \& Luca Enriques, Institutional Investor Activism in a Context of Concentrated Ownership and High Private Benefits of Control: The Case of Italy, in The Research Handbook on Shareholder Power 383 (Randall S. Thomas \& Jennifer G. Hill eds., 2015) (presenting anecdotal evidence that is consistent with the hypothesis that activists curb controlling shareholder rent seeking).

${ }^{94}$ Kastiel supra note 91 at 104-116 (analyzing how reputational concerns of controllers facilitate activist campaigns)

${ }^{95}$ Wertpapiererwerbs- und Übernahmegesetz [WpÜG], Dec. 20, 2001, BUNDESGESETZBLATT I BGBL. I, 3822, § 35 para. 2.

${ }^{96}$ Wertpapierhandelsgesetz [WpHG], July 26, 1994, BGBL. I 1749, § 21 para. 1

${ }^{97}$ Directive 2004/109/EC of the European Parliament and of the Council of 15 December 2004 on the harmonisation of transparency requirements in relation to information about issuers whose securities are admitted to trading on a regulated market and amending Directive 2001/34/EC, arts. 9-16, 2004 O.J. (L 390) 38.

${ }^{98}$ On the importance of private enforcement, see Rafael La Porta et al., Law and Finance, 106 J. PUB. ECON. 1113, 1128 (1998) (identifying an individual right to sue as a central component of efficient securities laws); the general hypothesis remains plausible even though recent literature shows the importance of the interplay between private and public enforcement measures, Howell E. Jackson \& Mark J. Roe, Public and Private Enforcement of Securities Laws: Resource-based Evidence, 93 J. FIN. ECON. 207 (2008); John C. Coffee, Jr., Law and The Market: The Impact of Enforcement, 156 U. PA. L. REV. 229 (2007).

${ }^{99}$ See supra note 47. 
Germany Inc. banks seized their monitoring function and left an unprecedented void with regard to related party transactions. Hence, a "traditionalist" stance which opposes law reform for related party transactions in Germany negatively affects capital market development, growth opportunities and ultimately social welfare. 


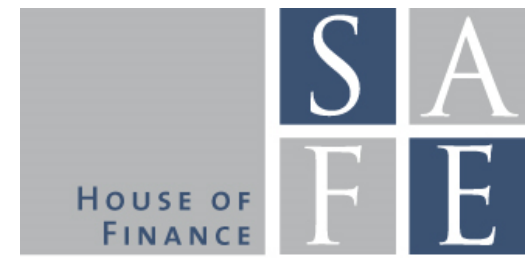

WORKING PAPER SERIES

\section{Recent Issues}

No. 201 Dirk Krueger, Alexander Ludwig

No. 200 Nils Grevenbrock, Max Groneck, Alexander Ludwig, Alexander Zimper

No. 199 Tobias H. Tröger

No. 198 Henning Hesse, Boris Hofmann, James Weber

No. 197 Benjamin Clapham, Peter Gomber, Martin Haferkorn, Paul Jentsch, Sven Panz

No. 196 Benjamin Clapham, Peter Gomber, Sven Panz

No. 195 Benjamin Clapham, Peter Gomber, Martin Haferkorn, Sven Panz

No. 194 Baptiste Massenot

No. 193 Mario Bellia, Roberto Panzica, Loriana Pelizzon, Tuomas Peltonen

No. 192 Vincenzo Pezone

No. 191 Julia Hirsch, Uwe Walz

No. 190 Vanya Horneff, Raimond Maurer, Olivia S. Mitchell

No. 189 Carlo Wix

No. 188 Michael Donadelli, Patrick Grüning, Marcus Jüppner, Renatas Kizys
Optimal Taxes on Capital in the OLG Model with Uninsurable Idiosyncratic Income Risk

Cognition, Optimism and the Formation of Age-Dependent Survival Beliefs

Regulation of Crowdfunding in Germany

The Macroeconomic Effect of Asset

Purchases Revisited

Circuit Breakers - A Survey among

International Trading Venues

Coordination of Circuit Breakers? Volume Migration and Volatility Spillover in Fragmented Markets

Managing Excess Volatility: Design and Effectiveness of Circuit Breakers

A Business Cycle Model with Neuroeconomic Foundations

The Demand for Central Clearing: To Clear or Not to Clear, That is the Question

The Real Effects of Judicial Enforcement: Evidence from Italy

Financial constraints, newly founded firms and the financial crisis

How Persistent Low Expected Returns Alter Optimal Life Cycle Saving, Investment, and Retirement Behavior

The Long-Run Real Effects of Banking Crises: Firm-Level Investment Dynamics and the Role of Wage Rigidity

Global Temperature, R\&D Expenditure, and Growth 